\title{
Synthesis of a Macrocyclic Mcl-1 Inhibitor
}

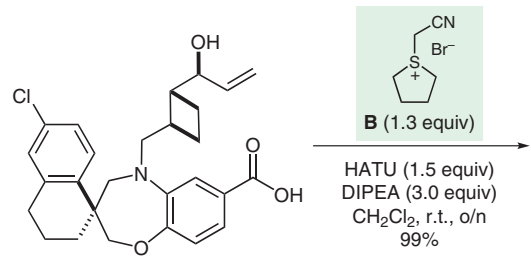

US 20160068545

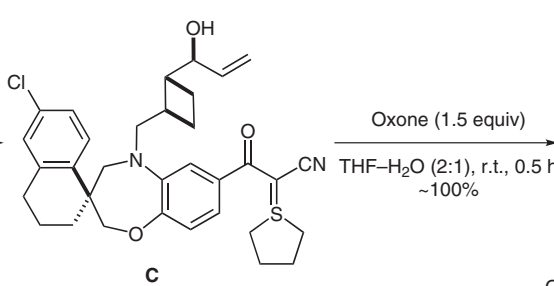

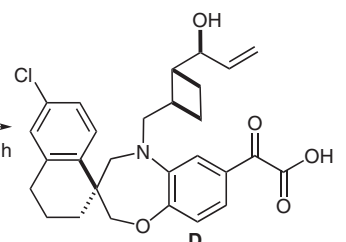

$\mathrm{ClCO}_{2} \mathrm{Me}$ (1.0 equiv)
$\mathrm{Et}_{3} \mathrm{~N}$ (1.0 equiv) $\mathrm{Et}_{3} \mathrm{~N}$ (1.0 equiv) $92 \%$ $\mathrm{CH}_{2} \mathrm{Cl}_{2}$, r.t., $1 \mathrm{~h}$<smiles>C=CC1CCC1CN1C[C@@]2(CCCc3cc(Cl)ccc32)COc2ccc(C(O)(CC(=C)O)C(=O)OC)cc21</smiles>
off-white solid

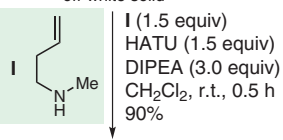<smiles>C=CCCN(C)C(=O)CC(O)(C(=O)OC)c1ccc2c(c1)N(CC1CCC1C(O)=[W])CC1(CCCc3cc(Cl)ccc31)CO2</smiles>
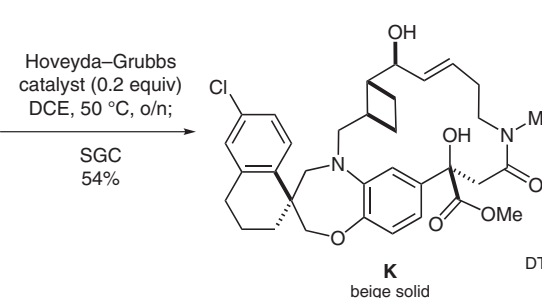

$\mathbf{K}$
beige solid

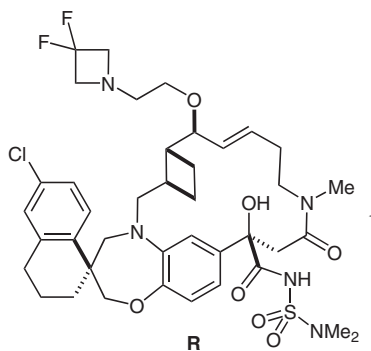

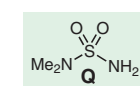

CDI (1.5 equiv) $\mathrm{CH}_{2} \mathrm{Cl}_{2}$, r.t., $2.5 \mathrm{~h}$ $\frac{\mathrm{Q} \text { (3 equiv) }}{\mathrm{DBU} \text { ( } 3 \text { equiv) }}$ r.t., o/n r.t., $\mathrm{o} / \mathrm{n}$
$70 \%$

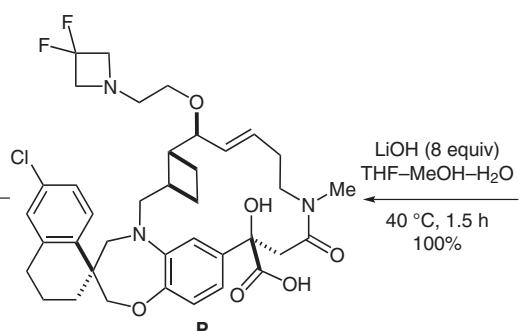

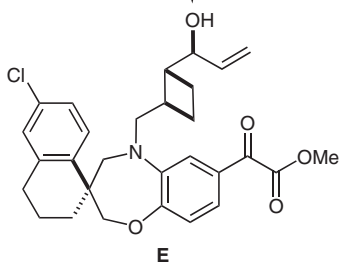

$\underset{\mathrm{dr}=2: 1}{\mathbf{G}}$ white solid

Category

Synthesis of Natural

Products and

Potential Drugs

\section{Key words}

Mcl-1 inhibitor

ring-closing metathesis

macrocyclization

Reformatsky reaction

$\alpha$-hydroxy phenylacetic acids
Significance: Overexpression of the antiapoptotic protein $\mathrm{Mcl}-1$ benefits survival of some cancer cells. The target molecule $\mathbf{R}$ is an inhibitor of $\mathrm{Mcl}-\mathbf{1}$. A key step in the synthesis depicted is the macrocyclization of diene $\mathrm{J}$ by ring-closing metathesis.
Comment: The addition of Reformatsky reagent $\mathbf{F}$ to the keto group in $\mathbf{E}$ generated a mixture of diastereoisomers $\mathbf{G}(\mathrm{dr}=2: 1)$ that was later separated by column chromatography to give the desired diastereoisomer $\mathbf{K}$. 